\title{
Peningkatan Minat dan Hasil Belajar Fikih Tentang Haji Melalui Metode Pembelajaran Aktif di MTsN 1 Kota Blitar
}

\author{
Mukhammad Luqman Hakim, Di'ama Farida Muharina \\ Institut Agama Islam Negeri (IAIN) Kediri, Indonesia \\ Jalan Sunan Ampel No. 7 Ngronggo Kota Kediri Jawa Timur \\ Email: mukh.luqman@iainkediri.ac.id
}

\begin{abstract}
Success in learning not only seen from the final results, but the process of learning is also a determinant of success in learning. The learning process can be done by creating fun learning, with the aim that students feel happy in the learning process. Based on observations at MTsN 1 Blitar City it can be seen that there is a decrease in students' interest in studying Fikih as happened in class VIII D MTsN 1 Blitar City. Decreased interest in learning has an impact on student learning outcomes. The purpose of this research is to overcome the problems that occur in the field by applying active learning methods. The method in this study uses action research with research subjects in class VIII D MTsN 1 Blitar City. The results of this study, students' interest and learning outcomes experienced a significant increase after active learning methods were applied. Data of learning interest increased from pre-cycle by $7.4 \%$, cycle I of interest in learning by $23.5 \%$, cycle II of interest in learning by $33.1 \%$, while for the average learning outcomes increased from pre-cycle of 54,70 , the first cycle of learning outcomes by 80 , the second cycle of learning outcomes by 84.61.Suggestions for other researchers to be able to make new innovations in the field of learning to solve problems that occur during the learning process.
\end{abstract}

Keywords: Active Laerning, Learning Interest and Learning Outcomes, Fikih

Abstrak:Keberhasilan pembelajaran tidak hanya dilihat dari hasil akhir saja, tetapi proses dalam pembelajaran juga menjadi penentu keberhasilan pembelajaran. Proses pembelajaran bisa dilakukan dengan menciptakan pembelajaran menyenangkan sehingga siswa merasa senang dan bahagia ketika belajar. Berdasarkan hasil observasi di MTsN 1 Kota Blitar dapat diketahui bahwa ada penurunan minat belajar siswa pada mata pelajaran Fikih. Penurunan minat belajar berdampak pada hasil belajar siswa. Tujuan dari penelitian ini adalah untuk mengatasi permasalahan yang terjadi dilapangan dengan menerapkan metode pembelajaran aktif. Metode dalam penelitian ini menggunakan penelitian tindakan dengan subjek penelitian siswa kelas VIII D MTsN 1 Kota Blitar. Hasil dari penelitian ini, minat dan hasil belajar siswa megalami peningkatan yang signifikan setelah diterapkan metode pembelajaran aktif. Hal ini terlihat dari data minat belajar Fikih meningkat dari pra siklus minat belajar sebesar 7,4\%, siklus I minat belajar sebesar 23,5 \%, siklus II minat belajar sebesar 33,1\%, sedangkan untuk rata-rata hasil belajar Fikih meningkat dari pra siklus sebesar 54,70, siklus I hasil belajar sebesar 80, siklus II hasil belajar sebesar 84,61. Saran untuk peneliti lain agar bisa melakukan inovasi baru menemukan solusi permasalahan yang terjadi terkait pembelajaran.

Kata Kunci: Pembelajaran Aktif, Minat dan Hasil Belajar, Pembelajaran Fikih

Jurnal Pendidikan Agama Islam Al-Thariqah Vol. 4, No. 2, Juli - Desember 2019

Received: 12 December 2019; Accepted: 18 December 2019; Published: 31 December 2019

*Corresponding Author: mukh.luqman@iainkediri.ac.id 


\section{PENDAHULUAN}

Keberhasilan dalam pembelajaran tidak hanya dilihat dari hasil akhir saja, akan tetapi proses dalam pembelajaran juga menjadi penentu keberhasilan dalam pembelajaran. Penyampaian pesan pembelajaran antara guru dengan siswa idealnya bisa dilakukan dengan proses interaksi dua arah. Keberhasilan pembelajaran tidak dilihat hanya dari hasil akhir saja, namun proses pembelajaran memiliki peran penting dalam keberhasilan pembelajaran (Semiawan). Proses pembelajaran bisa dilakukan dengan menciptakan pembelajaran yang menyenangkan (Enjoyfull Learning), dengan tujuan siswa merasa senang dan bahagia dalam proses pembelajaran (Elliott, 2010).

Pembelajaran yang menyenangkan dengan artian bahwa siswa merasa nyaman selama proses pembelajaran. Pembelajaran yang menyenangkan akan berdampak pada pemrosesan materi pelajaran mata pelajaran kedalam memori siswa. Berdasarkan teori sibermetik yang dikemukan oleh Robert M. Gagne (Gagne dan Medsker, 1995) ada tiga komponen dalam pemrosesan informasi, diantaranya yaitu: (1) Sensory Receptor (SR) yaitu sel pertama kali informasi diterima. Dalam SR informasi ditangkap dalam dalam bentuk aslinya, tanpa ada tambahan atau modifikasi, sehingga informasi yang diterima hanya bertahan dalam waktu singkat dan mudah terganggu dan terhanti; (2) Working Memory (WM) diasumsikan informasi yang masuk mendapat asumsi perhatian individu yang bersifat persepsi. Karakteristik WM berfsifat kapasitas terbatas yaitu mampu bertahan 15 menit dan informasi dapat disandikan dengan model yang berbeda dengan aslinya; dan (3) Long Term Memory (LTM) diasumsikan bahwa berisi semua pengetahuan yang telah dimiliki oleh individu, kapasitas penyimpanan yang tidak terbatas dan informasi yang masuk dalam LTM tidak pernah terhapus atau hilang.

Penerapan teori Sibermatik banyak diterepkan di beberapa strategi pembelajaran, salah satunya yaitu strategi pembelajaran siswa aktif. Pembelajaran aktif dapat diaplikasikan dengan banyak hal, diantaranya yaitu berkelompok, simulasi dan pembelajaran berbasis masalah (Allen dan Baughman, 2016). Dalam hal penilaian pembelajaran aktif bisa dilakukan dengan penialain individu maupun penilaian kelompok. Pembelajaran aktif siswa menjadi peran utama dalam proses pembelajaran, guru hanyalah menjadi fasilitator.

Berdasarkan hasil observasi di MTsN 1 Kota Blitar dapat diketahui bahwa ada penurunan minat belajar siswa pada mata pelajaran Fikih seperti yang terjadi di kelas VIII D MTsN 1 Kota Blitar. Penurunan minat belajar berdampak pada hasil belajar siswa. Hal ini terlihat dari hasil ulangan harian yang diikuti oleh 34 siswa, hanya 38,24\% atau 13 siswa yang tuntas dengan nilai mencapai KKM (Kriteria Ketuntasan Minimal) yaitu 80, sedangkan $61,76 \%$ atau 21 siswa belum bisa mencapai KKM dengan nilai rata-rata ualangan harian kelas VIII D adalah 54,71.

Peneliti berkesempatan berdiskusi langsung dengan guru mata pelajaran Fikih MTsN 1 Kota Blitar. Berdasarkan penuturan guru mata pelajaran Fikih, 
bahwa guru sudah menerapkan berbagai variasi dalam proses pembelajaran. Variasi pembelajaran yang sering diterapkan oleh guru berupa diskusi, demonstrasi dan metode tanya jawab. Meskipun guru sudah menerapkan berbagai strategi pembelajaran tetap saja pembelajaran masih berpusat pada guru dan belum mengoptimalkan peran peserta didik selama proses pembelajaran. Hal ini terlihat ketika proses diskusi sering didominasi oleh beberapa siswa saja, sedangkan siswa yang lain hanya menjadi penonton.

Berdasarkan permasalahan di atas peneliti berinisiatif untuk memberikan solusi dalam permasalahan proses pembelajaran. Berbagai strategi pembelajaran dapat diterapkan untuk mengatasi permasalahan dalam pembelajaran. Pemilihan strategi pembelajaran yang tepat akan berdampak pada proses pembelajaran yang kondusif dan berdampak pada hasil belajar siswa. Pembelajaran aktif merupakan salah satu strategi pembelajaran yang bisa mengoptimalkan peran setiap siswa selama proses pembelajaran. Pembelajaran aktif yang lebih interaktif, sedangkan metode konvensional siswa cepat merasa bosan, kurang kreatif, menampakkan kurang bersemangat dan kurang siap dalam menerima pelajaran, yang menyebabkan interaksi antara guru dan siswa jarang terjadi bahkan cenderung pasif yang pada akhirnya proses dan hasil belajar siswa belum sesuai harapan.

Untuk meningkatkan minat dan hasil belajar siswa, peneliti perlu melakukan tindakan yaitu menerapkan metode pembelajaran aktif dalam proses pembelajaran. Tindakan pertama yang dilakukan adalah menerapkan metode pembelajaran aktif dalam proses pembelajaran secara kelompok besar. Kelebihan metode ini siswa akan terlibat langsung di dalam percobaan sehingga bisa menemukan pengalaman sendiri dengan nyata, dan siswa akan lebih berminat dalam proses pembelajaran yang akan berpengaruh pada hasil belajarnya.

Tindakan kedua yang dilakukan adalah menerapkan metode pembelajaran aktif dalam kelompok kecil. Kelebihan metode ini, siswa akan lebih intens lagi dalam keterlibatannya secara langsung, sehingga untuk memperoleh pengalaman nyata yang lebih besar, dan semakin kuat dalam mengeksplorasi pengalamannya. Metode ini berupaya memadukan, menyinergikan dan mengelaborasikan faktor potensi diri manusia selaku pembelajar dengan lingkungan sebagai konteks pembelajaran. Dimana siswa di dalam dan di luar kelas dfikihndang sebagai suatu kelompok atau dibagi menjadi beberapa kelompok kecil.

Berdasarkan teori pembelajaran kelompok, kelebihannya adalah meningkatkan hasil belajar, baik secara kuantitatif maupun kualitatif, mengembangkan perasaan sosial dan pergaulan sosial yang baik dan meningkatkan rasa percaya diri anggota kelompok. Sehingga pembelajaran kelompok kemungkinan hasilnya akan menjadi lebih baik.

Secara sederhana penerapan metode pembelajaran aktif dapat meningkatan minat dan Hasil Belajar fikih materi haji 
bagi siswa kelas VIII D MTsN 1 Kota Blitar semester genap Tahun Pelajaran
2018/2019 dapat digambarkan dalam bentuk kerangka berpikir sebagai berikut:

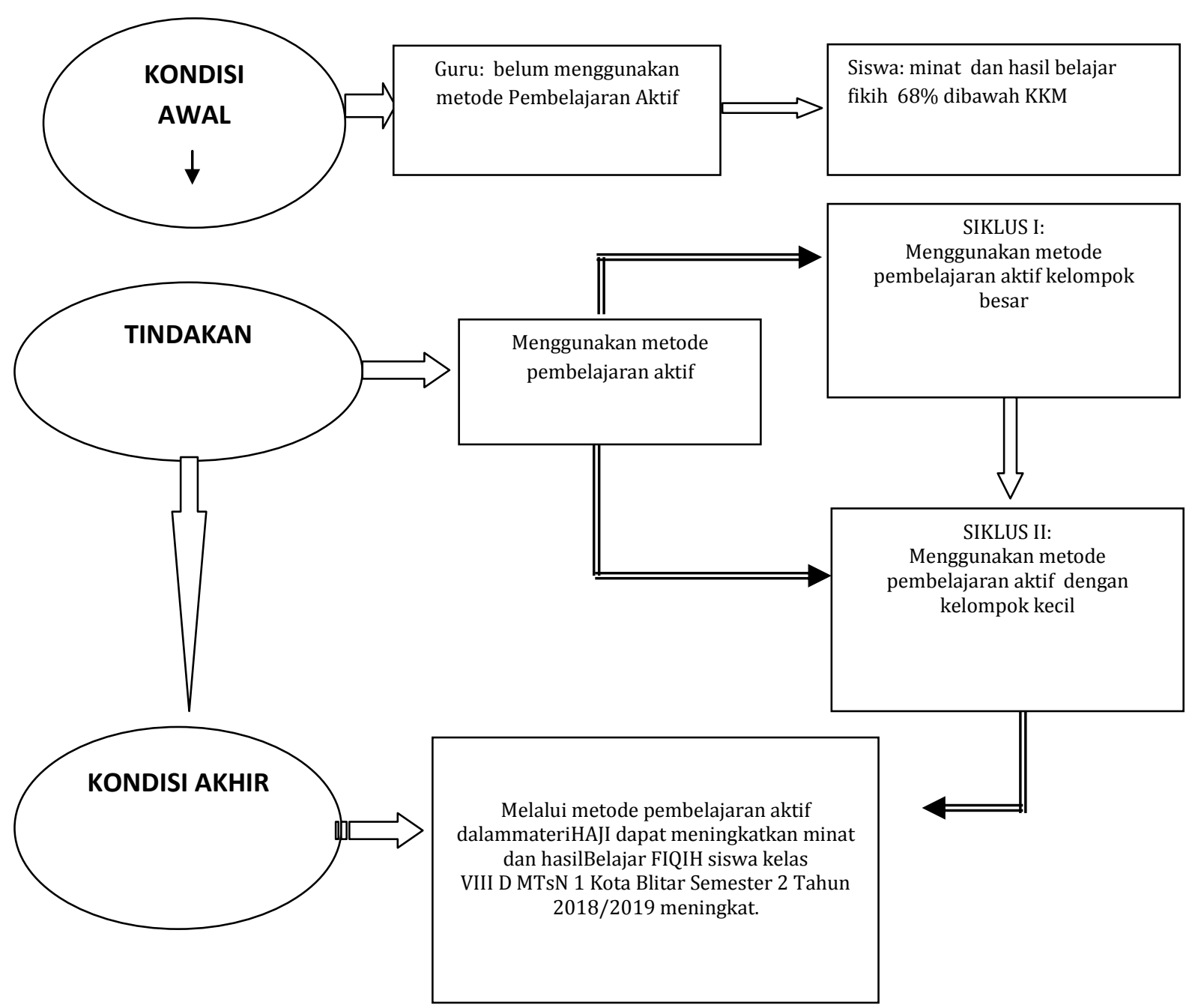

Gambar 1: Kerangka Berpikir

\section{KONSEP TEORI}

Dalam perspektif Islam, suatu metode pembelajaran hendaknya mampu memberikan bekal peserta didik untuk bisa cakap dalam kehidupan, baik ketika berada di sekolah atau di luar sekolah. Menurut Qodri Azizi, ada beberapa ketentuan dalam pemilihan metode dalam perspektif islam, diantaranya yaitu: (1) metode pembelajaran harus mampu memberikan pengalaman belajar yang sesuai nilai-nilai Islam atau akhlak mulia; (2) memberikan pemahaman materi keislaman secara menyeluruh dan sesuai dengan syariat (Azizy, 2003).

Pendidikan agama Islam bertujuan memberi pengasuhan dan membina peserta didika agar selalu memahami dan mengamalkan ajaran agama Islam secara menyeluruh sampai pada akhirnya menjadikan islam sebagai pandangan hidup (Daradjat, 1984). Mata pelajaran 
fikih termasuk kedalam rumpun mata pelajaran pendidikan agama Islam. Mata pelajaran Fikih merupakan salah satu mata pelajaran wajib di jenjang Madrasah Tsanawiyah. Fikih memiliki karakteristik mata pelajaran yang membutuhkan pemahaman secara menyeluruh karena terkait hukum-hukum syariat Islam.

Pembelajaran Fikih pada hakikatnya memiliki fungsi yang tertuang dalam kurikulum MGMP mata pelajaran Fikih (Hamalik, 2010), yaitu: (1) menyiapkan pengetahuan tentang Islam dalam aspek hukum, baik dalam hal ibadah maupun muamalah sebagai bekal dunia dan akhirat; (2) sebagai pengetahuan dan kemampuan mengamalkan ajaran Islam yang diperoleh di jenjang pendidikan; (3) menanamkan sikap dan nilai keteladanan terhadap syariat Islam; (4) meningkatkan iman dan taqwa kepada Allah SWT.

Konsep belajar siswa aktif merupakan metode pembelajaran yang memberikan banyak kesempatan siswa untuk bisa mengembangkan kemampuan berfikirnya baik perorangan maupun kelompok (Silberman, 2009). Pembelajaran aktif salah satunya dapat diaplikasikan dengan metode percobaan. Metode percobaan siswa bisa mengalami secara langsung materi yang sedang diajarkan dan mencari penyelesaian permasalahan sendiri.

Minat belajar merupan dorongan internal dan ekternal untuk belajar. Setiap individu menyadari akan pentingnya suatu hal yang berarti, maka individu terebut akan berusaha dengan berbagai cara untuk mendapatkan apa yang dia inginkan(DePorter). Dalam belajar Fikih, ketika siswa mempunyai kepentingan dalam proses belajar maka ia akan akan berusaha memusatkan perhatian pada proses pembelajaran yang sedang berlangsung.

Sedangkan hasil belajar merupakan hasil perubahan tingkah laku setiap individu. Hasil belajar dibagi menjadi tiga bagian, yaitu hasil belajar kognitif, hasil belajar psikomotor dan hasil belajar afektif. Dalam penelitian ini, hasil belajar Fikih yang diharapkan bisa meningkat adalah hasil belajar kognitif. Dengan penerapan metode pembelajaran siswa aktif diharapkan mampu meningkatkan minat dan hasil belajar kognitif siswa.

\section{METODE PENELITIAN}

Metode penelitian yang digunakan merupakan penelitian tindakan (Action Research). Penelitian tindakan bertujuan untuk menelusuri dan mendapatkan informasi terkait permasalahan dan dapat memberikan solusi terhadapa permasalahan yang terjadi. Dalam penelitian ini terbagi menjadi empat tahap, yakni: perencanaan, tindakan, observasi dan refleksi. Subjek penelitian adalah siswa kelas VII D MTsN 1 Blitar dengan jumlah 34 siswa. Teknik pengumpulan data pada penelitian ini menggunakan teknik observasi, sedangkan untuk alat pengumpulan data berupa: (1) data minat belajar siswa pada kondisi awal menggunakan catatan jurnal pembelajaran kondisi awal; (2) data minat belajar siswa di setiap siklus menggunakan lembar observasi; (3) data hasil belajar kondisi awal, menggunakan catatan daftar nilai; (4) data hasil belajar di setiap siklus menggunakan butir soal tes tertulis. 
Penelitian dilakukan sebanyak dua siklus, dimana setiap siklus dilaksanakan selama satu minggu. Berikut ini skema langkah-langkah tindakan pada siklus I dan siklus II:

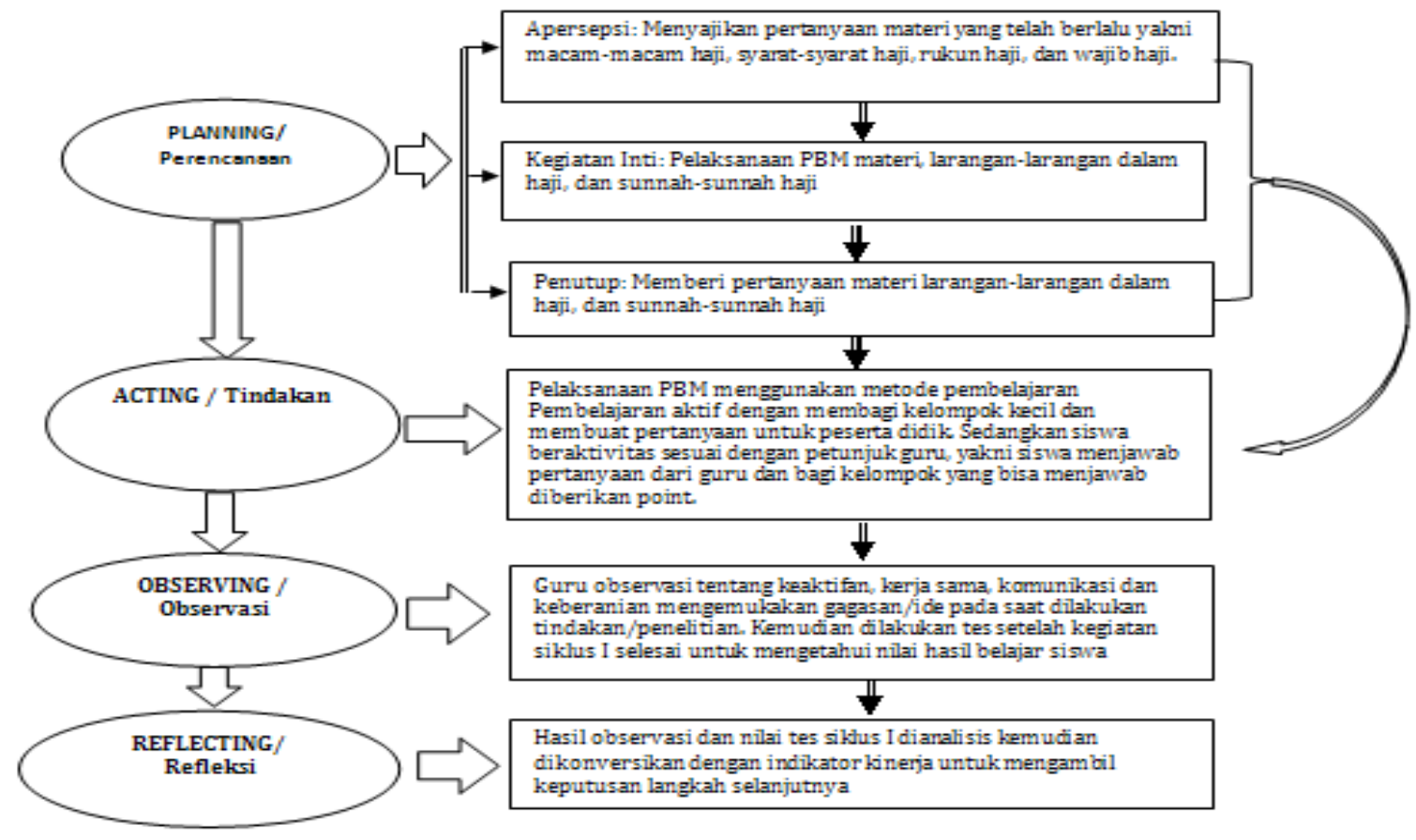

Gambar 2 : Langkah-langkah tindakan pada siklus I

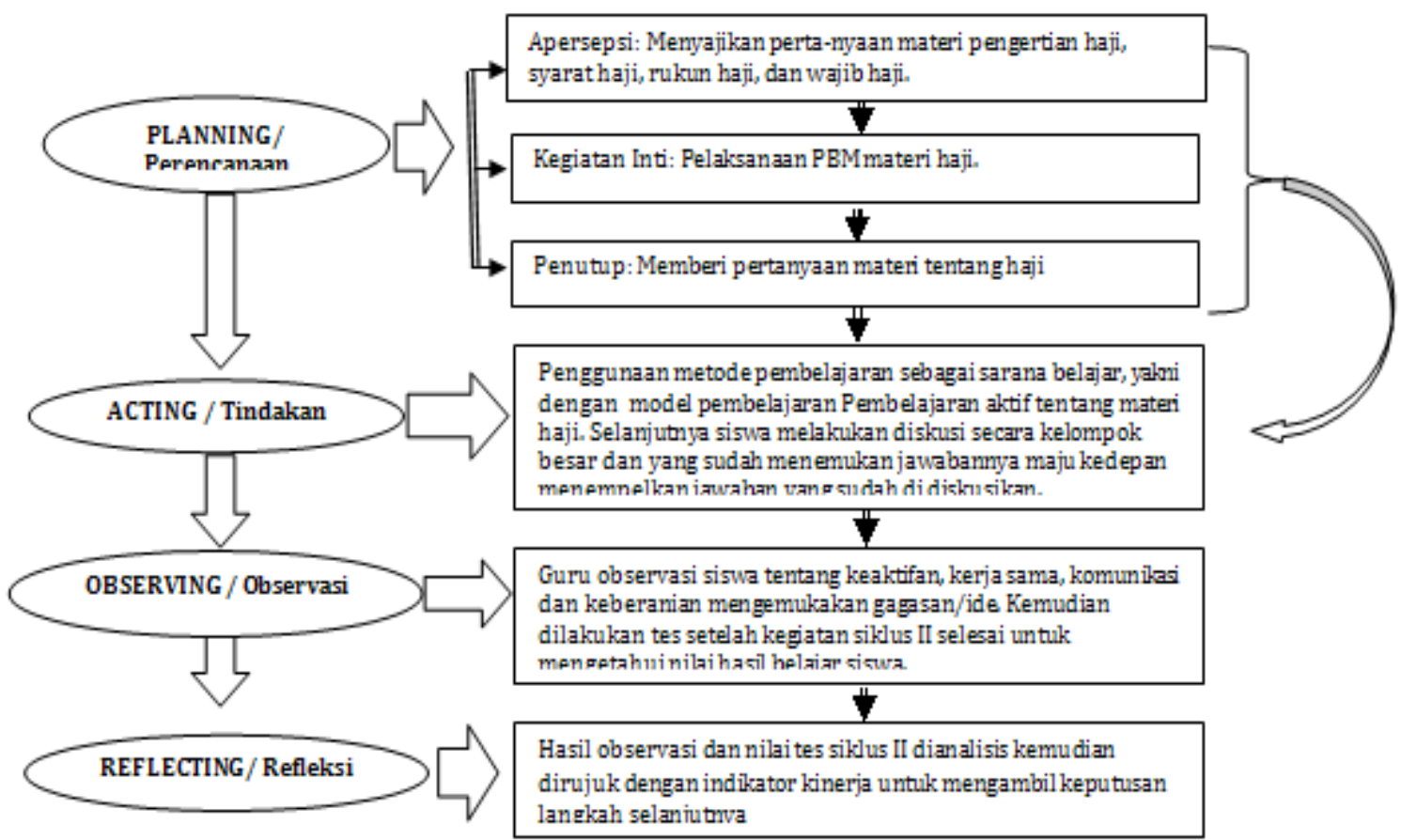

Gambar 3 : Langkah-langkah tindakan pada siklus II 


\section{HASIL DAN PEMBAHASAN}

\section{Deskripsi Data Kondisi Awal}

Kondisi awal dalam penelitian ini dijumpai adanya permasalahan tingkat minat pada pembelajaran fikih masih rendah. Hal ini bisa dilihat dari data pengamatan dokumen catatan harian jurnal mengajar, anak yang selalu bertanya ada 2 anak, sering bertanya 1 anak, kadang bertanya 5 anak, dan tidak pernah bertanya 26 anak. Sedangkan anak yang selalu berani menjawab pertanyaan 2 anak, sering menjawab 3 anak, kadang menjawab 7 anak, sedangkan 29 anak tidak berani menjawab. Dalam menyampaikan ide atau pendapat, ada 3 anak yang selalu menyampaikan idenya, 4 anak yang sering menyampaikan ide atau pendapat, sementara anak yang kadang saja menyampaikan ide atau pendapatnya 4 anak dan yang tidak pernah 23 anak. Sementara itu, anak yang selalu antusias dalam menerima pelajaran 3 anak, yang sering antusias 1 anak, kadang antusias 9 anak, dan 21 anak tidak pernah antusias serta terdapat kurangnya minat belajar kelas VIII D dan sering sekali nilai baik UH, UTS tidak pernah tuntas, hanya beberapa saja yang tuntas dari 34 siswa yang tuntas hanyalah sekitar 12 anak dan yang 22 siswa tidak tuntas.

\begin{tabular}{|c|l|c|c|c|c|}
\hline No & \multicolumn{1}{|c|}{ Uraian } & Bertanya & Menjawab & Menyampaikan Ide & Antusias \\
\hline 1 & Selalu & 2 & 2 & 3 & 3 \\
\hline 2 & Sering & 1 & 3 & 4 & 1 \\
\hline 3 & Kadang & 5 & 7 & 4 & 9 \\
\hline 4 & Tidak Pernah & 26 & 29 & 23 & 21 \\
\hline & Total & 34 & 34 & 34 & 34 \\
\hline
\end{tabular}

Tabel 1:Minat Belajar Fikih Kondisi Awal

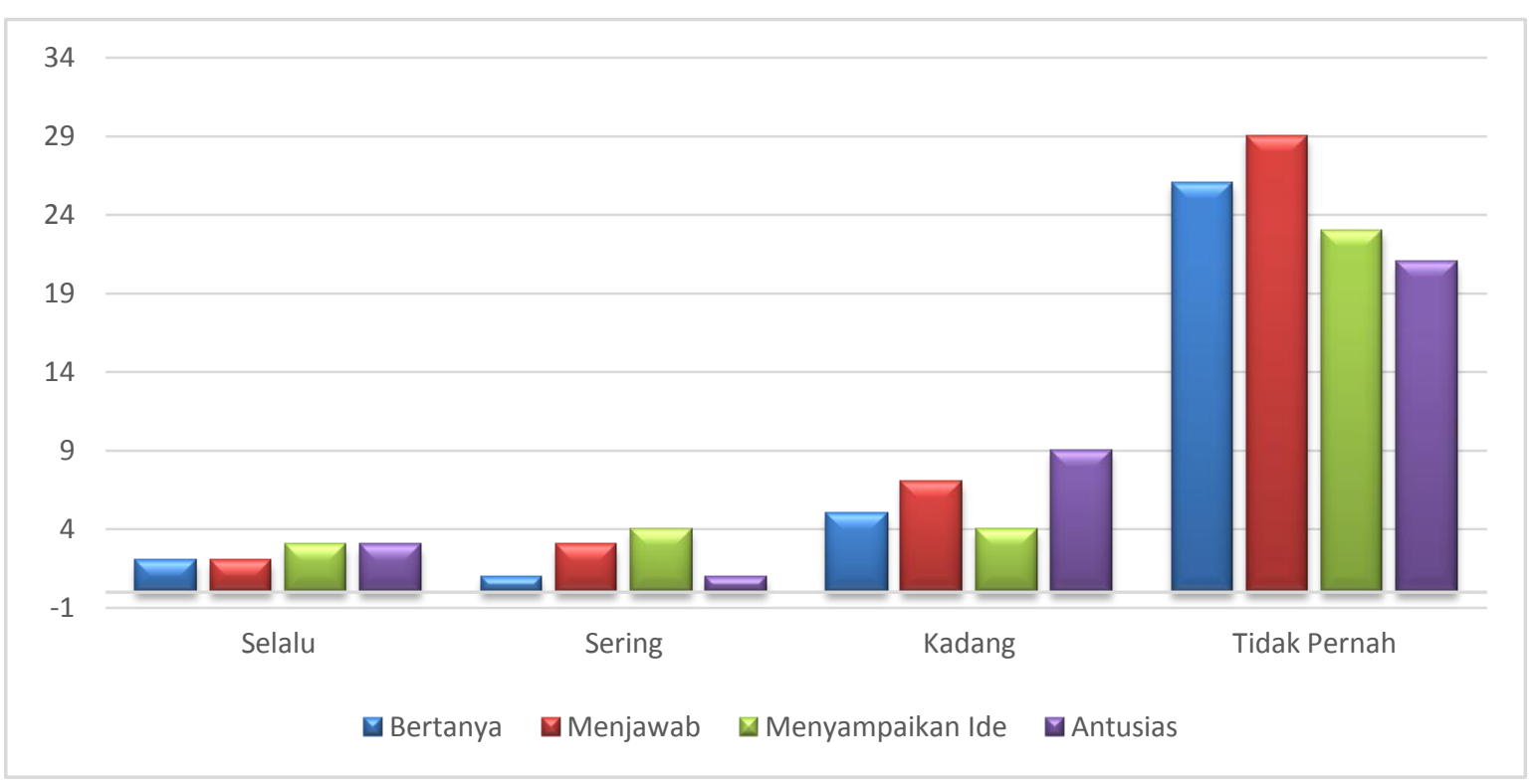

Gambar 3: Diagram minat belajar siswa pada saat kondisi awal 


\section{Deskripsi Data Hasil Belajar Fikih}

Berdasarkan data minat belajar pada kondisi awal yang rendah, ternyata berdampak pada hasil belajar yang relatif rendah, berikut pemaparan data hasil belajar dapat dilihat pada tabel 1 :

\begin{tabular}{|c|l|c|}
\hline No & \multicolumn{1}{|c|}{ Uraian } & Hasil Belajar \\
\hline 1 & Nilai tertinggi & 85 \\
\hline 2 & Nilai terendah & 40 \\
\hline 3 & Nilai Rerata & 54.71 \\
\hline 4 & Rentang Nilai & 50 \\
\hline
\end{tabular}

Tabel 1: Hasil Belajar Fikih Kondisi Awal

Tampak pada diagram diatas nilai terendahnya 35 dan nilai rerata hanya tertinggi pada ulangan harian ini 85 , nilai 54.71 dan rentang nilai adalah 50 .

\begin{tabular}{|c|c|c|c|c|}
\hline No & Interval Nilai & Frekuensi & $\begin{array}{c}\text { Persentase } \\
(\%)\end{array}$ & \multirow{2}{*}{ Rata-rata } \\
\cline { 1 - 3 } 1 & $40-49$ & 13 & 38 & \multirow{3}{*}{54.71} \\
\cline { 1 - 3 } 2 & $50-59$ & 6 & 18 & \\
\cline { 1 - 3 } 3 & $60-69$ & - & 6 & \\
\cline { 1 - 4 } 5 & $70-79$ & 13 & 38 & \\
\hline & $80-89$ & 34 & 100 & \\
\hline
\end{tabular}

Tabel 2: Interval hasil belajar Fikih kondisi awal atau pra siklus

Dari Tabel 2 di atas hanya 38\% siswa dapat mencapai batas tuntas yang distandarkan yaitu 80 sedangkan sisanya
$62 \%$ tidak mencapai standar ketuntasan. Kondisi tersebut juga dapat dilihat pada diagram berikut:

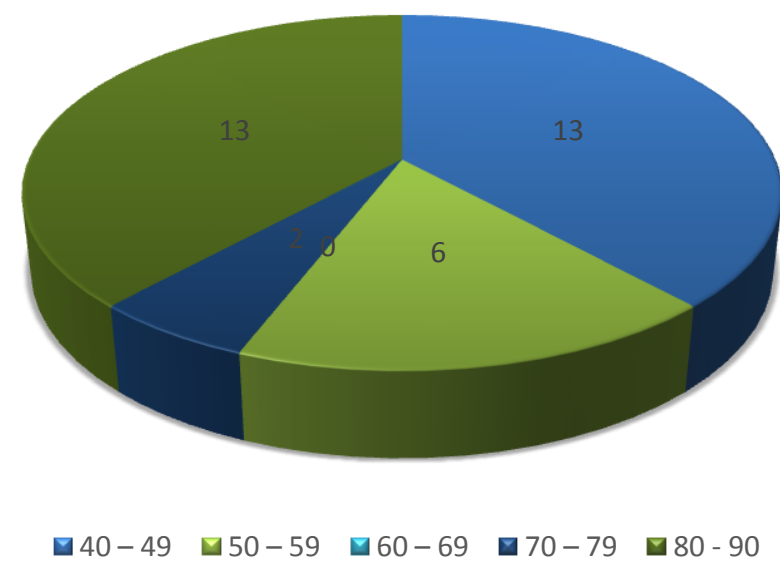

Gambar 5: Diagram interval hasil belajar Fikih pada kondisi awal 


\section{Deskripsi Data Hasil Siklus I}

Data Minat Belajar Fikih

Pembelajaran pada siklus I dalam penelitian ini tingkat minat pada pembelajaran fikih sudah terjadi peningkatan. Hal ini bisa dilihat dari data pengamatan, anak yang selalu bertanya ada 6 anak, sering bertanya 20 anak, kadang bertanya 7 anak, dan tidak pernah bertanya 1 anak. Sedangkan anak yang selalu berani menjawab pertanyaan 10 anak, sering menjawab 16 anak, kadang menjawab 7 anak, sedangkan 1 anak tidak berani menjawab. Dalam menyampaikan ide atau pendapat, ada 3 anak yang selalu menyampaikan idenya, 23 anak yang sering menyampaikan ide atau pendapat, sementara anak yang kadang saja menyampaikan ide atau pendapatnya 7 anak dan yang tidak pernah 1 anak. Sementara itu, anak yang selalu antusias dalam menerima pelajaran 15 anak, yang sering antusias 14 anak, kadang antusias 3 anak, dan 1 anak tidak pernah antusias.

\begin{tabular}{|c|l|c|c|c|c|}
\hline No & Uraian & Bertanya & Menjawab & Menyampaikan Ide & Antusias \\
\hline 1 & Selalu & 6 & 10 & 3 & 15 \\
\hline 2 & Sering & 20 & 16 & 23 & 14 \\
\hline 3 & Kadang & 7 & 7 & 7 & 3 \\
\hline 4 & Tidak Pernah & 1 & 1 & 1 & 1 \\
\hline \multicolumn{2}{|c|}{ Total } & 34 & 34 & 34 & 34 \\
\hline
\end{tabular}

Tabel 3:Minat Belajar Fikih Siklus I

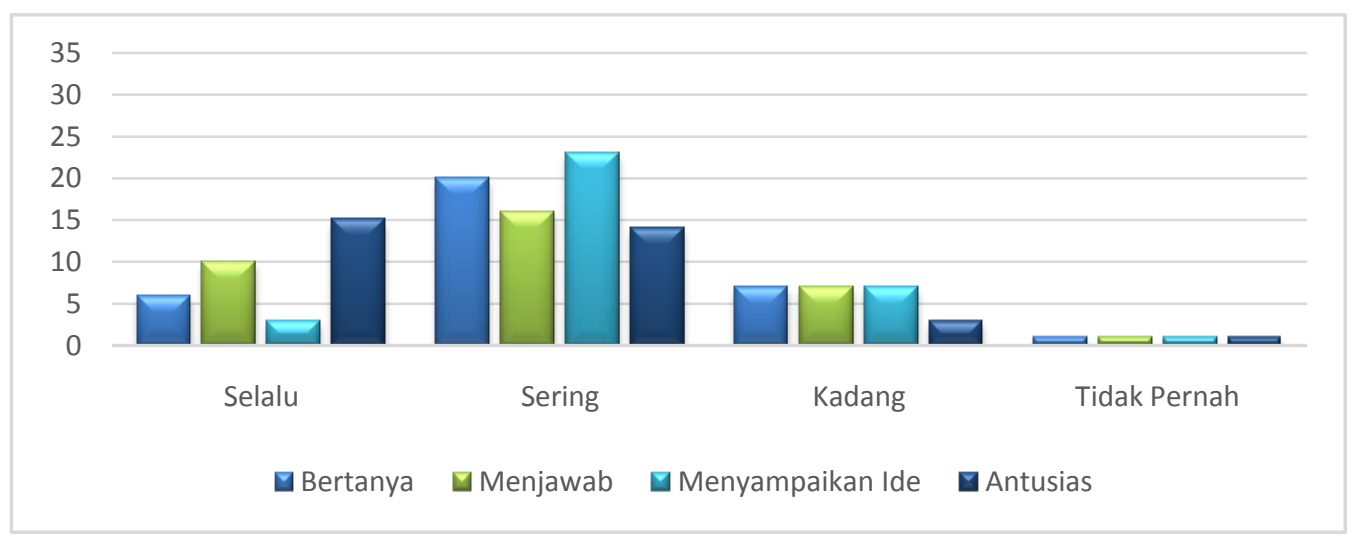

Gambar 6: Diagram Minat Belajar Fikih pada Siklus I

\section{Data Hasil Belajar Fikih}

Peningkatan minat belajar anak pada siklus I cukup signifikan, berdampak pada hasil belajar. pada nilai ulangan harian siklus I ini, nilai tertinggi 100, nilai terendah 60 dan reratanya 80 . Hal ini bisa dilihat pada tabel 4 berikut ini:

\begin{tabular}{|c|l|c|}
\hline NO & \multicolumn{1}{|c|}{ URAIAN } & HASIL BELAJAR \\
\hline 01 & Nilai tertinggi & 100 \\
02 & Nilai terendah & 60 \\
03 & Nilai Rerata & 80 \\
04 & Rentang Nilai & 60 \\
\hline
\end{tabular}


Tabel 4: Hasil belajar Fikih pada siklus I

Sedangkan distribusi nilai ulangan harian siklus I dapat dilihat pada tabel berikut:

\begin{tabular}{|c|c|c|c|c|c|}
\hline No & Interval Nilai & Frekuensi & Kategori & $\begin{array}{c}\text { Prosentase } \\
(\%)\end{array}$ & $\begin{array}{c}\text { Rata- } \\
\text { Rata }\end{array}$ \\
\hline 1 & $60-69$ & 12 & Kurang & 35 & \\
\hline 2 & $70-79$ & 16 & Cukup & 47 \\
\hline 3 & $80-89$ & 1 & Baik & 3 & \multirow{2}{*}{80} \\
\cline { 1 - 5 } 4 & $90-100$ & 5 & $\begin{array}{c}\text { Amat } \\
\text { baik }\end{array}$ & 15 & \\
\hline & Jumlah & 34 & & 100 & \\
\hline
\end{tabular}

Tabel 5: Distribusi Frekuensi dan Rata-Rata Skor Ulangan Harian pada Siklus I

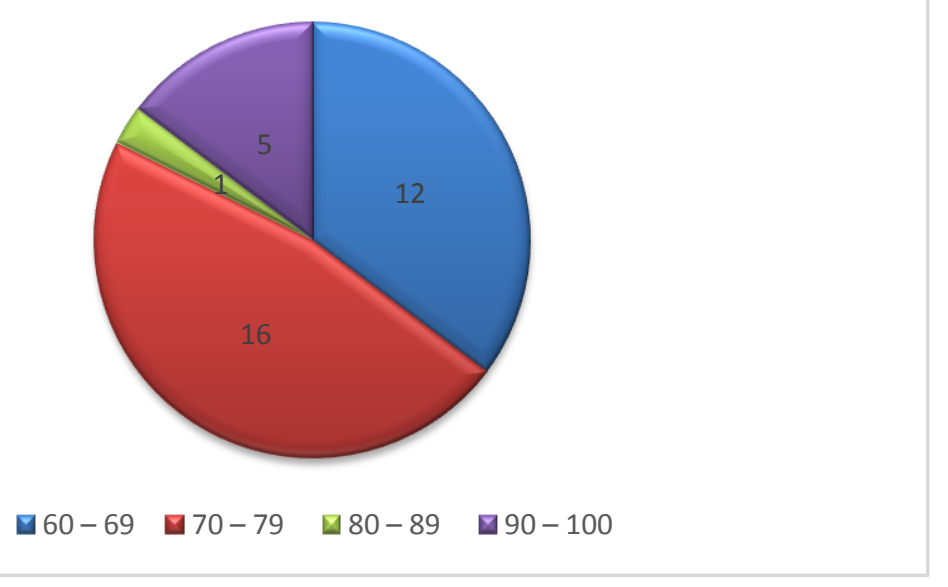

Gambar 7: Prosentase hasil belajar siklus I

Berdasarkan Tabel 5 nampak bahwa distribusi nilai Ulangan Harian Siklus 1 frekuensi tertinggi berada pada rentang nilai 70 - 79 sebanyak 16 siswa (47\%) dan yang terendah berada pada rentang 90-

\section{Refleksi Siklus I}

Refleksi Data Minat Belajar Fikih

Data minat belajar Fikih meningkat cukup signifikan dari kondisi awal minat belajar terlihat rata-rata $7,4 \%$, setelah pelaksanaan siklus I minat belajar yang naik sebesar 23,5 \%. Maka dapat
100 sebanyak 5 siswa atau (15\%). Frekuensi terendah terjadi pada rentang nilai 80 sampai dengan 89 yakni 1 siswa (3\%) dan berada pada kategori baik.

disimpulkan bahwa melalui metode pembelajaran aktif dapat meningkatkan minat belajar fikih materi Haji kelas VIII D MTsN 1 Kota Blitar semester genap Tahun 2018/2019.

Refleksi Data Hasil Belajar

Data hasil belajar Fikih meningkat cukup signifikan. Hal ini terlihat dari 
kondisi awal nilai terendah 40naik menjadi 60 sedangkan tertinggi naik dari 85 menjadi 100. Dan Nilai rerata meningkat dari 54,71 menjadi 80. Dengan demikian dapat disimpulkan bahwa melalui metode Pembelajaran aktif dapat meningkatkan hasil belajar Fikih materi Haji kelas VIII D MTsN 1 Kota Blitar semester 2 Tahun 2018/2019.

\section{Deskripsi Data Hasil Pengamatan Siklus II}

Data Minat Belajar Fikih

Pembelajaran pada siklus II dalam penelitian ini tingkat minat pada pembelajaran fikih terjadi peningkatan yang cukup signifikan. Hal ini bisa dilihat dari data pengamatan, anak yang selalu bertanya ada 15 anak, sering bertanya 15 anak, kadang bertanya 3 anak, dan tidak pernah bertanya 1 anak. Sedangkan anak yang selalu berani menjawab pertanyaan 10 anak, sering menjawab 16 anak, kadang menjawab 7 anak, sedangkan 1 anak tidak berani menjawab.

Dalam menyampaikan ide atau pendapat, ada 9 anak yang selalu menyampaikan idenya, 19 anak yang sering menyampaikan ide atau pendapat, sementara anak yang kadang saja menyampaikan ide atau pendapatnya 6 anak dan yang tidak pernah 0 anak. Sementara itu, anak yang selalu antusias dalam menerima pelajaran 11 anak, yang sering antusias 20 anak, kadang antusias 3 anak, dan 0 anak tidak pernah antusias.

Berikut ini pemaparan data hasil minat belajar Fikih pada tabel 6:

\begin{tabular}{llcccc}
\hline No & Uraian & Bertanya & Menjawab & $\begin{array}{c}\text { Menyampaikan } \\
\text { Ide }\end{array}$ & Antusias \\
\hline 1 & Selalu & 15 & 10 & 9 & 11 \\
\hline 2 & Sering & 15 & 16 & 19 & 20 \\
\hline 3 & Kadang & 3 & 7 & 6 & 3 \\
\hline 4 & Tidak Pernah & 1 & 1 & 0 & 0 \\
\hline
\end{tabular}

Tabel 6: Minat Belajar Fikih Siklus II

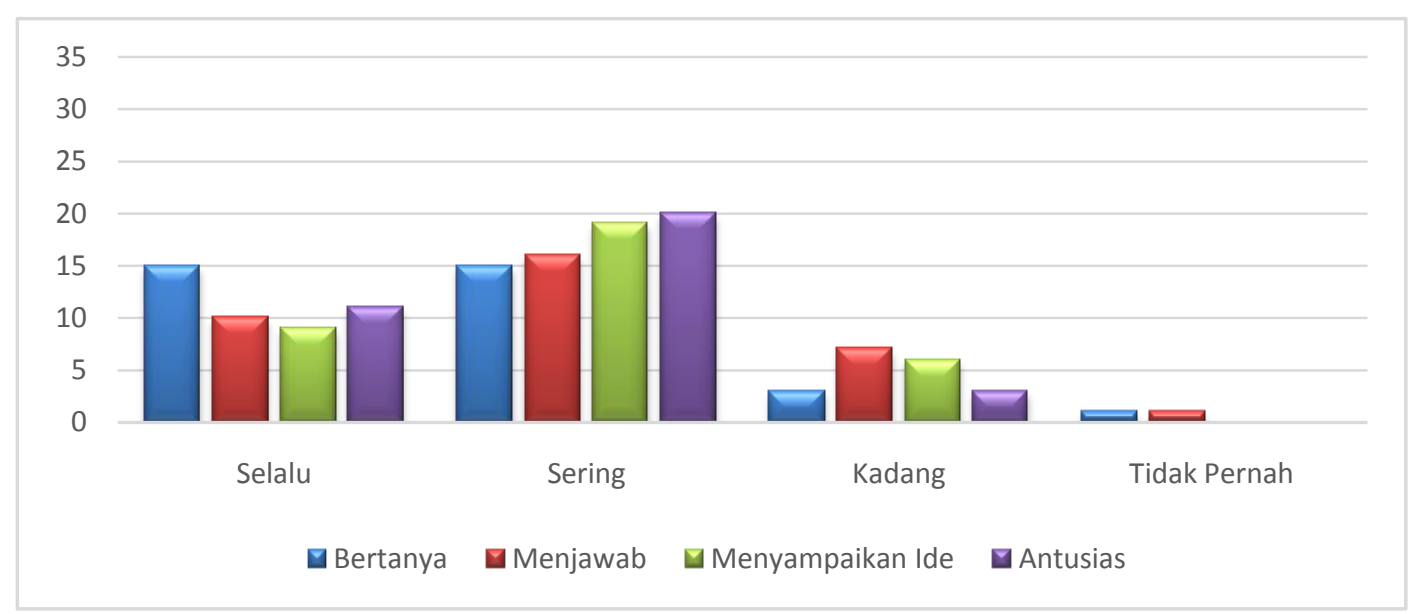

Gambar 7:Diagram Minat Belajar Fikih pada Siklus II

\section{Data Hasil Belajar Siswa Siklus II}

Peningkatan minat belajar anak pada siklus I yang cukup signifikan, berdampak pada hasil belajar yang baik pula. Didapatkan pada nilai ulangan harian 
siklus II ini, nilai tertinggi 100 , nilai terendah 70 dan reratanya 84 . Hal ini bisa dilihat pada tabel 7 berikut:

\begin{tabular}{|l|c|c|}
\hline No & Uraian & Hasil Belajar \\
\hline 1 & Nilai tertinggi & 100 \\
\hline
\end{tabular}

\begin{tabular}{|l|l|l|}
\hline 2 & Nilai terendah & 66 \\
\hline 3 & Nilai Rerata & 86 \\
\hline 4 & Rentang Nilai & 70 \\
\hline
\end{tabular}

Tabel 7: Hasil Belajar Fikih Siklus II

\begin{tabular}{cccccc}
\hline No & Interval Nilai & Frekuensi & Kategori & $\begin{array}{c}\text { Prosentase } \\
(\%)\end{array}$ & Rata-rata \\
\cline { 1 - 5 } 1 & $60-69$ & 4 & Kurang & 11 & \\
\cline { 1 - 5 } 2 & $70-79$ & 3 & Cukup & 8 \\
\cline { 1 - 4 } 3 & $80-89$ & 19 & Baik & 55 \\
\cline { 1 - 4 } 4 & $90-100$ & 8 & Amat baik & 23 & \\
\cline { 1 - 4 } & Jumlah & 34 & & 100 & \\
\hline
\end{tabular}

Tabel 8: Distribusi frekuensi dan rata-rata skor ualangan harian pada siklus II

Berdasarkan Tabel diatas nampak bahwa distribusi nilai Ulangan Harian Siklus II frekuensi tertinggi berada pada rentang nilai 80 - 89 sebanyak 19 siswa (55\%) dan yang terendah pada rentang 60 -69 kategori kurang sebanyak 4 siswa atau (4\%) dan rentang 90 - 100 kategori amat baik juga ada 8 siswa atau 23\%. Rata-rata Ulangan Harian pada siklus 2 sebesar $84,61 \%$ berada pada kategori cukup dan mencapai batas tuntas.Dari hasil yang diperoleh di atas dapat dilihat pada diagram berikut:

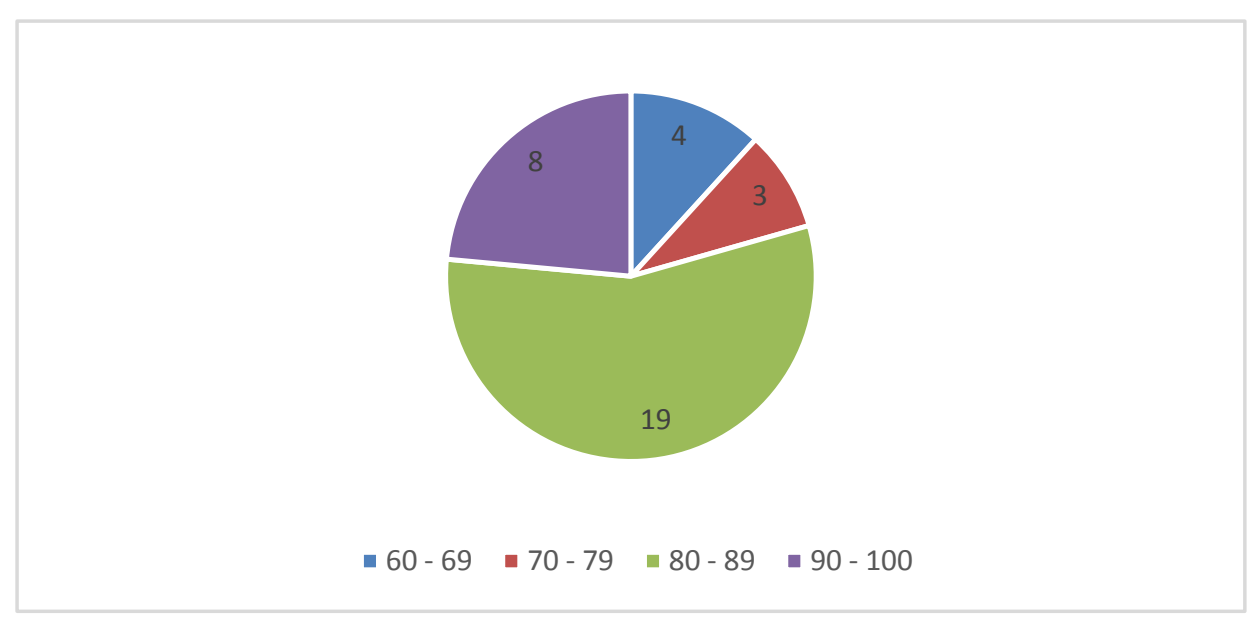

Gambar 8. Prosentase hasil belajar siklus II

\section{Refleksi Siklus II}

Refleksi Data Minat Belajar Fikih

Data minat belajar Fikih meningkat dari pra siklus minat belajar sebesar 7,4 $\%$, siklus I minat belajar sebesar 23,5 \%, setelah pelaksanaan siklus II minat belajar sebesar 33,1\%. Sehingga dapat disimpulkan bahwa metode pembelajaran aktif dapat meningkatkan minat belajar fikih materi Haji kelas VIII D MTsN 1 Kota Blitar semester genap Tahun 2018/2019. 


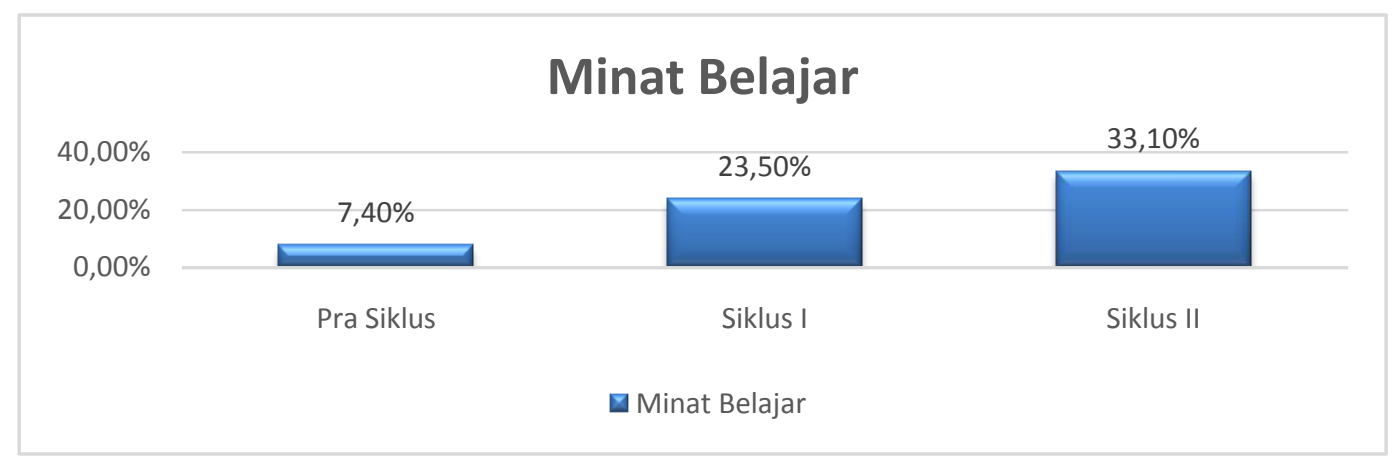

Gambar 9: Peningkatan minat belajar

Refleksi Data Hasil Belajar Fikih

Data rata-rata hasil belajar Fikih meningkat dari pra siklus hasil belajar sebesar 54,70, siklus I hasil belajar sebesar 80, setelah pelaksanaan siklus II hasil belajar sebesar 84,61. Sehingga dapat disimpulkan bahwa metode pembelajaran aktif dapat meningkatkan hasil belajar fikih materi Haji kelas VIII D MTsN 1 Kota Blitar semester genap Tahun 2018/2019

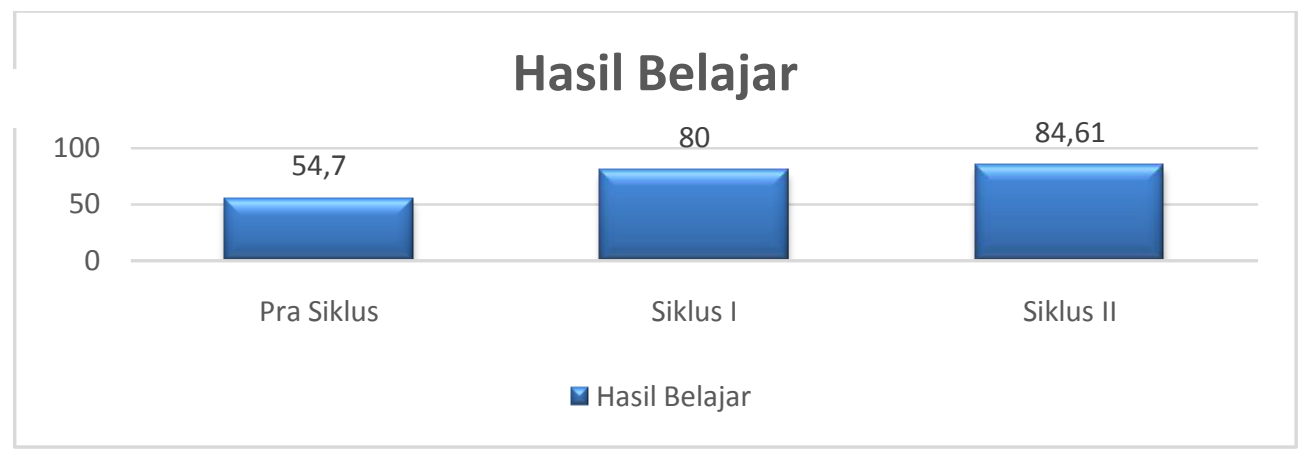

Gambar 10: Peningkatan hasil belajar

\section{PENUTUP}

Berdasarkan uraian diatas, maka dapat ditarik kesimpulan sebagai berikut: (1) Melalui penerapan metode pembelajaran aktif materi Haji dapat meningkatkan hasil belajar Fikih bagi siswa kelas VIII D MTsN 1 Kota Blitar semester genap Tahun Pelajaran 2018/2019; (2) Melalui penerapan metode pembelajaran aktifmateri Haji dapat meningkatkan minat belajar Fikih bagi siswa kelas VIII D MTsN 1 Kota Blitar semester genap Tahun Pelajaran 2018/2019.[]

\section{DAFTAR RUJUKAN}

Allen, Peter J., and Frank D. Baughman. "Active Learning in research methods classes is associated with higher knowledge and confidence, though not evaluations or satisfaction." Frontiers in psychology 7 (2016): 279.

Azizy, Qodri. Islam dan Permasalahan Sosial: Mencari Jalan Keluar. Pustaka Pelajar, 2003.

Daradjat, Zakiah. Dasar-dasar agama Islam: buku teks pendidikan agama Islam pada perguruan tinggi umum. Bulan Bintang, 1984.

DePorter, Bobbi. Quantum Teaching. PT Mizan Publika, 2000. 
Elliott, Lisa Jo, dkk. "Research Participation versus Classroom Lecture: A Comparison of Student Learning." Teaching of Psychology 37.2 (2010): 129-131.

Gagne, Robert M., dan Karen L. Medsker. The Conditions of Learning: Training Applications. 1 edition, Wadsworth Publishing, 1995.

Hamalik, Oemar. Belajar Mengajar Fiqih. Buku Beta, 2010.

Semiawan, Conny R. Penerapan pembelajaran pada anak. Indeks, 2009.

Silberman, Melvin L. Active Learning: 101 Strategi Pembelajaran Aktif. Pustaka Insan Madani, 2009. 